\title{
ATSIGAVIMO PRIEMONIŲ POVEIKIS BLAUZDOS RAUMENŲ FUNKCINEI BŪKLEI IR KRAUJOTAKAI PO STATINIO FIZINIO KRŪVIO
}

\author{
Albinas Grūnovas ${ }^{1}$, Jonas Poderys ${ }^{1}$, Danguolè Grūnoviene் $\dot{e}^{2}$ \\ Lietuvos kūno kultūros akademijal , Kauno kolegija', Kaunas, Lietuva
}

\begin{abstract}
Albinas Grūnovas. Biomedicinos mokslų daktaras, e. prof. p. Lietuvos kūno kultūros akademijos Individualių sporto šakų katedroje. Moksliniu tyrimų kryptis — periferinès ir sisteminès kraujotakos kaita fizinio krūvio metu ir taikant atsigavimą skatinančias priemones.
\end{abstract}

\section{SANTRAUKA}

Sportininko organizmo darbinguma ir atsigavima po sekinamu fiziniu krūviu lemia daugelis veiksniu, iš ju ypač reikšminga raumenu kraujotakos kaita. Nuo fiziologiniu reguliavimo mechanizmu ir ju tarpusavio sqveikos priklauso galutinis rezultatas — kraujotakos intensyvumas, todèl siūlomi ̌vairūs organizmo kraujotakos aktyvinimo būdai, tarp ju papildomos atsigavimo priemonés. Tyrimo tikslas - išanalizuoti atsigavimo priemoniu — pasyviojo poilsio (PP), griaučiu raumenu elektrostimuliacijos (RES), pasyvaus pédu lenkimo ir tiesimo (PPL) - poveiki funkcinei raumenu būklei ir kraujotakai po statinio fizinio krūvio.

Buvo tiriami 22 prisitaike prie ištvermès krūviu sportininkai. Arterinei kraujotakai ramybès sqlygomis registruoti naudota venu okliuzine pletizmografija, pédos lenkiamuju raumenu jègai matuoti — dinamometrija. Išmatavus maksimaliaja valinga jèga, tiriamieji atliko du lokalius statinius fizinius krūvius (pasipriešinimas - 75\% maksimaliosios valingos jégos) iki visiško nuovargio. Po pirmo ir antro statinio krūvio praejjus $305 \mathrm{~s}$, buvo registruojama arterinès kraujotakos kaita blauzdos raumenyse. Tarp abieju fiziniu krūviu daroma 20 min pertrauka. Po pirmo statinio krūvio užregistravus kraujotakos rodiklius, buvo taikomos trys atsigavimo priemonés: PP, RES, PPL.

Tyrimo rezultatai parodè, kad prieš statini fizini krūvi pasyvaus poilsio grupès sportininku arterine kraujotaka buvo 2,7 \pm 0,2 $\mathrm{ml} / \mathrm{min} / 100 \mathrm{ml}$, tuojau pat po krūvio padidejo 52,4 \pm 3,3 $\mathrm{ml} / \mathrm{min} / 100 \mathrm{ml}(\mathrm{p}<0,001)$, praejus $305 \mathrm{~s}$ po krūvio ir po $P P-4,0 \pm 0,3 \mathrm{ml} / \mathrm{min} / 100 \mathrm{ml}(p<0,05)$. Prieš statinífizinị krūvi elektrostimuliacijos grupés sportininku arterine kraujotaka buvo 2,6 0,2 $\mathrm{ml} / \mathrm{min} / 100 \mathrm{ml}$, tuojau pat po krūvio padidejo 55,8 $\pm 3,4 \mathrm{ml} / \mathrm{min} / 100 \mathrm{ml}$ $(p<0,001)$, praejus 305 s po krūvio ir po RES - 3,3 $\pm 0,3 \mathrm{ml} / \mathrm{min} / 100 \mathrm{ml}(\mathrm{p}>0,05)$. Prieš statini fizinį krūvi pasyvaus pédu lenkimo ir tiesimo grupés tiriamuju arterinè kraujotaka buvo 2,8 \pm 0,2 $\mathrm{ml} / \mathrm{min} / 100 \mathrm{ml}$, tuojau pat po krūvio padidèjo 51,3 $\pm 2,7 \mathrm{ml} / \mathrm{min} / 100 \mathrm{ml}$ (p <0,001), praejjus $305 \mathrm{~s}$ po krūvio ir po $P P L-3,1 \pm 0,3 \mathrm{ml} / \mathrm{min} / 100 \mathrm{ml}$ $(p>0,05)$. RES ir PPL po fizinio krūvio teigiamai veike arterinès kraujotakos intensyvuma ir kraujotakos grižima $\dot{ }$ pradini lygi. Atlikus RES, pédos lenkiamuju raumenu darbingumas padidèjo 0,2\%, po PPL - 8,2\%, po PP sumažèjo 8,2\%. Po antro statinio fizinio krūvio kraujotakos kaita buvo tokia pat kaip ir po pirmo.

Apibendrinant galima teigti, kad tokios papildomos atsigavimo priemonès kaip pasyvus pèdu lenkimas ir tiesimas, raumenu ektrostimuliacija po statinio fizinio krūvio paspartina pédos lenkiamuju raumenu darbingumo atsigavima. Tiek raumenu elektrostimuliacija, tiek pasyvūs pédu judesiai organizmo atsigavimo laikotarpiu padidina arterinés kraujotakos intensyvuma ir ji greičiau grižta i pradini lygì.

Raktažodžiai: raumenu darbingumas, raumenu kraujotaka, atsigavimo priemonès.

\section{IVADAS}

$\mathrm{S}$ portininko organizmo darbingumą ir atsigavimą po sekinamų fizinių krūviu lemia daugelis veiksnių, iš jų ypač reikšminga raumenų kraujotakos kaita. Ivairūs fiziologiniai reguliavimo mechanizmai ir jų tarpusavio sąveika lemia galutini rezultata - kraujotakos intensyvumą. Ieškodami geresnio šios problemos sprendimo būdo, tyrèjai siūlo aktyvinti kraujotaką papildomomis atsigavimo priemonemis. Kiekviena aktyvi atsigavimo priemonè yra papildomas krūvis, veikiantis daugeli organizmo funkciniu sistemu. Vis dẻlto dažnai pasirenkamos ir pasyvios atsigavimo priemonès. Daugelis tyrèju pripažista, kad aktyvios atsigavimo priemonès yra veiksmingesnès negu pasyvios (Crisafulli et al., 2003; Platonov, 2004). Elektros procedūros sportininkų organizmą veikia specifiškai. Jos gali stimuliuoti atsigavimą po konkrečios raumenu veiklos ir pasirinktinai 
aktyvinti funkcines sistemas prieš sporto pratybas arba varžybas. Griaučių raumenų elektrostimuliacija dažniausiai taikoma sutrikus raumens funkcijai ir atgaunant ją po ligų (Sweeney, 1998; Lavec et al., 2008). Dar mažai žinoma, kaip fibriliacinis susitraukimas (elektromasažas) veikia raumenu kraujotaką po fizinių krūvių, nors elektrostimuliacija plačiai naudojama treniruočiu programose raumenų darbingumui didinti (Theriault et al., 1996; Maffiulleti et al., 2000, 2002, 2006; Malatesta et al., 2003; Brocherie et al., 2005).

Nenutrūkstami $60 \mathrm{~s}$ trukmès pasyvūs pèdos lenkimo judesiai mažina nelankstumą per kulkšnies sąnari (Mcnair et al., 2001), pasyvus ir aktyvus lenkimas didina kraujo tekejjimo greiti (Sochart, Hardinge, 1999), o nenutrūkstami 10 min pasyvūs judesiai, atliekami mechaniniu prietaisu, skatina venini kraują greičiau grižti iš apatiniu galūnių po kulkšnies sąnario operacijų (Bonnaire et al., 1994). Mechaninis poveikis kraujagyslèms yra vienas savęs reguliavimo fenomenu, sukeliantis vazodilatacinį atsaką (Boutcher, Boutcher, 2005). Kaip pasyvūs pėdų lenkimo ir tiesimo judesiai bei griaučių raumenų elektrostimuliacija fibriliaciniais susitraukimais veikia arterinès kraujotakos intensyvumą po lokalaus statinio darbo, dar netirta. Raumenu kraujotakos ir darbingumo sąsaja taip pat nèra nuodugniai ištirta (Hughson et al., 1996: Gonzalez-Alonso et al., 2008).

Tyrimo tikslas - išanalizuoti atsigavimo priemonių - pasyviojo poilsio (PP), griaučiu raumenų elektrostimuliacijos (RES), pasyvaus peddu lenkimo ir tiesimo (PPL) - poveikį raumenu funkcinei būklei ir kraujotakai po statinio fizinio krūvio.

\section{TYRIMO METODIKA}

Labai intensyvų darbą gali atlikti sportininkai, prisitaikę prie ištvermès fizinių krūvių. Kita vertus, atsigavimo priemonių taikymas po ištvermès fizinių krūvių yra labai aktuali problema. Todèl buvo tiriami 22 vidutinių ir ilgujų nuotolių bègikai (jų amžius $-21 \pm 1,0$ m., ūgis $-182,1 \pm 1,2 \mathrm{~cm}$, kūno masè $-70,0 \pm 1,7 \mathrm{~kg}$ ). Ištvermę lavinančių sportininku grupę sudarè geriausi Lietuvos kūno kultūros akademijos, Kauno miesto ir Lietuvos vidutinių bei ilgujų nuotolių bėgikai. Visi tiriamieji atsitiktine tvarka buvo suskirstyti $i$ tris grupes pagal jiems taikomas atsigavimo priemones: pirmai grupei buvo taikoma PP $20 \mathrm{~min}$, PP $10 \mathrm{~min}+10 \mathrm{~min}$ RES, PP $5 \mathrm{~min}+$ PPL $15 \mathrm{~min}$; antrai - PP $10 \min +10 \min$ RES, PP 5 min + PPL 15 min, PP 20 min; trečiai - PP 5 min + PPL 15 min, PP 20 min, PP 10 min + 10 min RES. Toks priemoniu kaitaliojimas reikalingas tam, kad tiriamiesiems nebūtų treniravimosi ir adaptacijos efekto eksperimento sąlygomis. Tyrimų diena sportininkai neturejjo treniruočių ar pratybų krūvio. Visu grupių tyrimai vyko darant dviejų dienų poilsio pertrauką. Per kiekvieną tyrimą buvo atliekami du fiziniai krūviai, tarp ju -20 min pertrauka (Macarez, 1976). Visų tyrimų metu po $20 \mathrm{~min}$ adaptacijos, sportininkui sedint ant dinamometrinès kèdès, pletizmografu buvo registruojamas arterinio kraujo kiekis blauzdos raumenyse, matuojama pėdos lenkiamujų raumenų maksimalioji valinga jëga ir atliekamas lokalus statinis darbas iki visiško nuovargio (pasipriešinimas - 75\% maksimaliosios valingos jègos). Po pirmo ir antro statinių krūvių praejus $305 \mathrm{~s}$, buvo registruojami blauzdos raumenu kraujotakos pokyčiai.

RES buvo atliekama elektrostimuliatoriumi (Mioritm 021, Kiev). Naudota impulsų amplitudinè-dažninè moduliacija, impulsų dažnis — nuo $20 \mathrm{iki} 120 \mathrm{~Hz}$, jaudinimo ir poilsio trukme $-1: 1$ $(2-2 \mathrm{~s})$. Elektrodu dydis $-20 \times 3 \mathrm{~cm}^{2}$. Vienas elektrodas dedamas ant blauzdos raumenu proksimaliosios, kitas - ant distaliosios dalies nugarinio paviršiaus. Elektros signalo stiprumas buvo parenkamas kiekvienam sportininkui individualiai pagal nervų ir raumenų atsaka, t. y. fibriliaciniu režimu, kai matomi pavienių raumeninių skaidulu grupių susitraukimai, tačiau visas raumuo nesusitraukia. Vienu metu buvo stimuliuojami abiejų blauzdu raumenys. Optimalus RES poveikis, po kurio pasiekiamas didžiausias darbingumas, trunka $10 \mathrm{~min}$ (Кибиша и др., 1983).

Pasyvūs pèdų judesiai buvo atliekami mechaniniu prietaisu (Кибиша и др., 1980): pèdos pritvirtinamos prie pedalu, kuriuos valde elektros variklis. Pedos lenkimo ir tiesimo judesių amplitudè -35 laipsniai, dažnis - 30 judesių per minutę. Optimalus PPL poveikis, po kurio pasiekiamas didžiausias darbingumas, trunka 15 min (Кибиша и др., 1983).

Matematinė statistika. Buvo skaičiuojami visu grupių rodikliu aritmetiniai vidurkiai ir aritmetinio vidurkio paklaidos. Imčių vidurkių lygybè vertinta pagal Studento $t$ kriterijų. Skirtumas $\mathrm{p}<0,05$ buvo laikomas patikimu. Prieš tikrinant vidurkių lygybę buvo patikrinama dispersijų lygybè. Skaičiavimai atlikti naudojantis statistiniu Microsoft Excel paketu ir specializuotaja statistikos programa Statistika. 


\section{REZULTATAI}

Pasyviojo poilsio grupès sportininkų maksimalioji raumenų ištvermė buvo 74,02 $\pm 2,96 \mathrm{~s}$, tuojau pat po PP sumažèjo iki $68,8 \pm 3,4 \mathrm{~s}$; reikšmiu skirtumo pokytis sudare $5,22 \pm 1,97 \mathrm{~s}(\mathrm{p}<0,05)$. Pasyviai ilsintis, pédos lenkiamujų raumenų darbingumas po antro statinio fizinio krūvio labai sumažèjo.

Elektrostimuliacijos grupès tiriamujų maksimalioji raumenų ištvermé buvo $72,5 \pm 2,06 \mathrm{~s}$, tuojau pat po RES $-72,53 \pm 2,81 \mathrm{~s}$; reikšmiu skirtumo pokytis sudare $0,08 \pm 1,76 \mathrm{~s}(\mathrm{p}>0,05)$. Stimuliuojamų griaučių raumenų darbingumas po antro fizinio krūvio nesumažèjo, išliko pradinio dydžio.

Pasyvaus pėdų lenkimo ir tiesimo grupès sportininku maksimalioji raumenu ištvermė buvo $72,07 \pm 3,01 \mathrm{~s}$, tuojau pat po PPL ji padidèjo iki $77,71 \pm 3,26 \mathrm{~s}$; reikšmiu skirtumo pokytis sudarè $5,64 \pm 1,69 \mathrm{~s}(\mathrm{p}<0,05)$. Pasyviai lenkiant ir tiesiant pėdas, griaučių raumenų darbingumas po antro fizinio krūvio labai padidejo. Papildomos atsigavimo priemonès (RES ir PPL) gerino dirbančiu raumenų fizini darbingumą.

Pasyvaus poilsio grupès sportininkų prieš statini fizini krūvi arterine kraujotaka buvo $2,7 \pm 0,2 \mathrm{ml} / \mathrm{min} / 100 \mathrm{ml}$, tuojau pat po krūvio padidejo $(52,4 \pm 3,3 \mathrm{ml} / \mathrm{min} / 100 \mathrm{ml}, \mathrm{p}<0,001)$, praejjus $305 \mathrm{~s}$ buvo $8,1 \pm 0,7 \mathrm{ml} / \mathrm{min} / 100 \mathrm{ml}$, $\mathrm{p}<0,001$ (1 ir 3 pav.). Po fizinio krūvio pasyviai ilsintis arterinès kraujotakos intensyvumas $(4,0 \pm 0,3 \mathrm{ml} / \mathrm{min} / 100 \mathrm{ml}, \mathrm{p}<0,05-5,0 \mathrm{~s}$; $3,8 \pm 0,3 \mathrm{ml} / \mathrm{min} / 100 \mathrm{ml}, \mathrm{p}<0,05-28 \mathrm{~s}$; $3,6 \pm 0,2 \mathrm{ml} / \mathrm{min} / 100 \mathrm{ml}, \mathrm{p}<0,05-52 \mathrm{~s}$; $3,7 \pm 0,2 \mathrm{ml} / \mathrm{min} / 100 \mathrm{ml}, \mathrm{p}<0,05-73 \mathrm{~s}$ ) buvo daug didesnis, palyginti su pradiniu dydžiu $(2,7 \pm 0,2 \mathrm{ml} / \mathrm{min} / 100 \mathrm{ml})(2 \mathrm{pav}$. $)$.

Prieš statinị fizinị krūvị elektrostimuliacijos grupès sportininkų arterinė kraujotaka buvo $2,6 \pm 0,2 \mathrm{ml} / \mathrm{min} / 100 \mathrm{ml}$, tuojau pat po krūvio padidèjo $(55,8 \pm 3,4 \mathrm{ml} / \mathrm{min} / 100 \mathrm{ml}, \mathrm{p}<0,001)$, praejjus $305 \mathrm{~s}-7,8 \pm 0,9 \mathrm{ml} / \mathrm{min} / 100 \mathrm{ml}$, $\mathrm{p}<0,001$ (1 ir 3 pav.). Po fizinio krūvio stimuliuo-

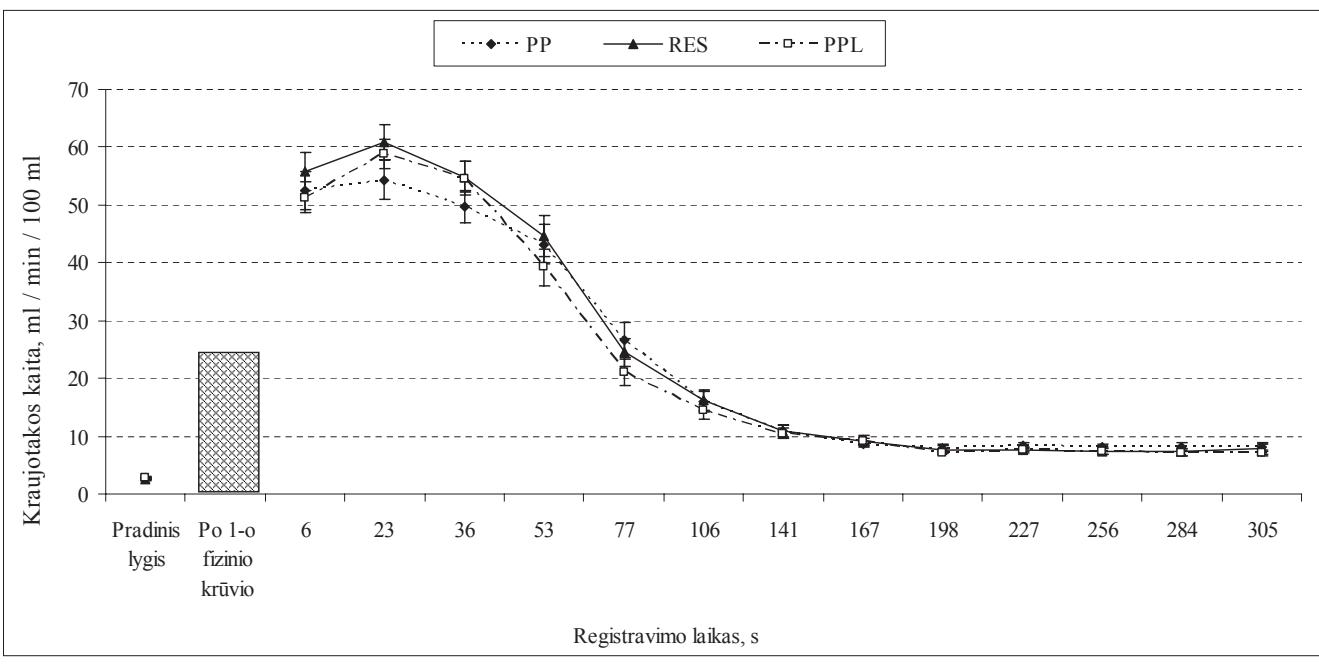

1 pav. Blauzdos raumenų arterinès kraujota$\operatorname{kos}(\mathrm{ml} / \min / 100 \mathrm{ml})$ kaita po pirmo statinio fizinio krūvio $(75 \%$ maksimaliosios valingos jègos iki visiško nuovargio)

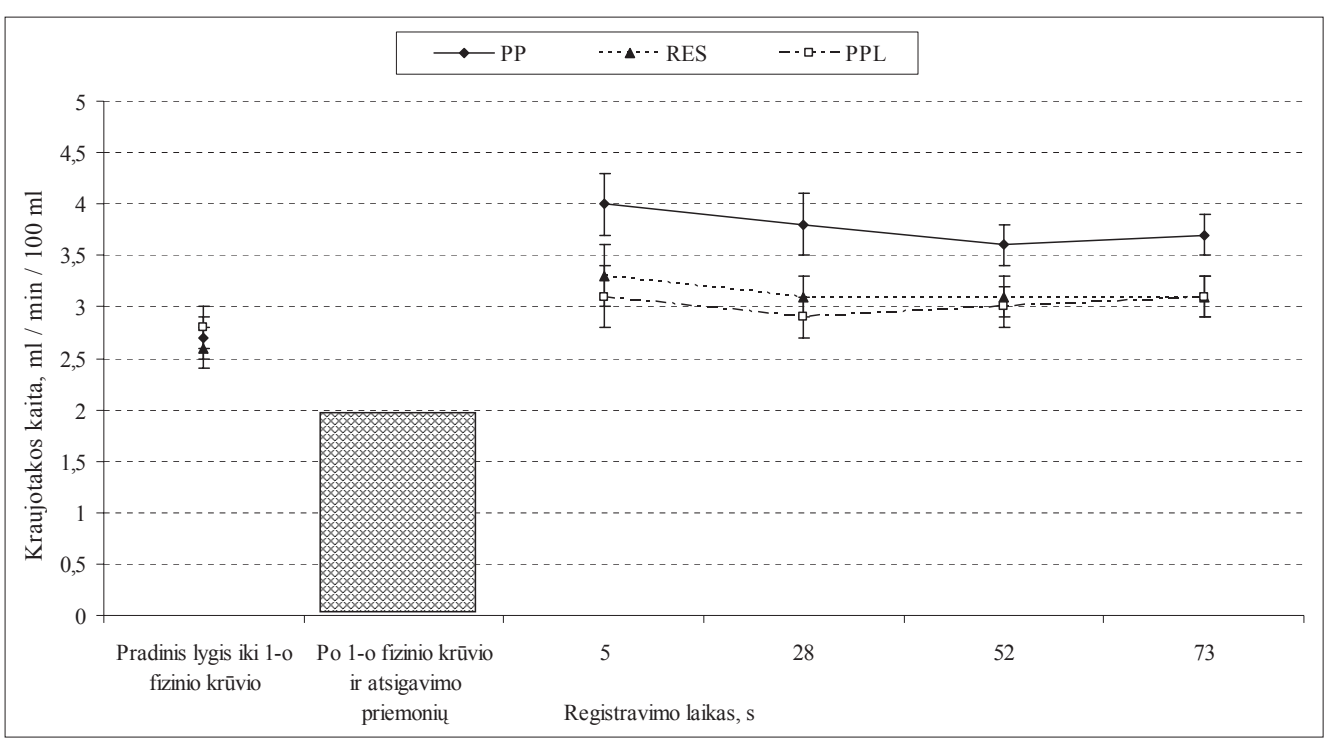

2 pav. Blauzdos raumenų arterinès kraujota$\operatorname{kos}(\mathrm{ml} / \mathrm{min} / 100 \mathrm{ml})$ kaita po pirmo statinio fizinio krūvio ir atsigavimo priemonių 


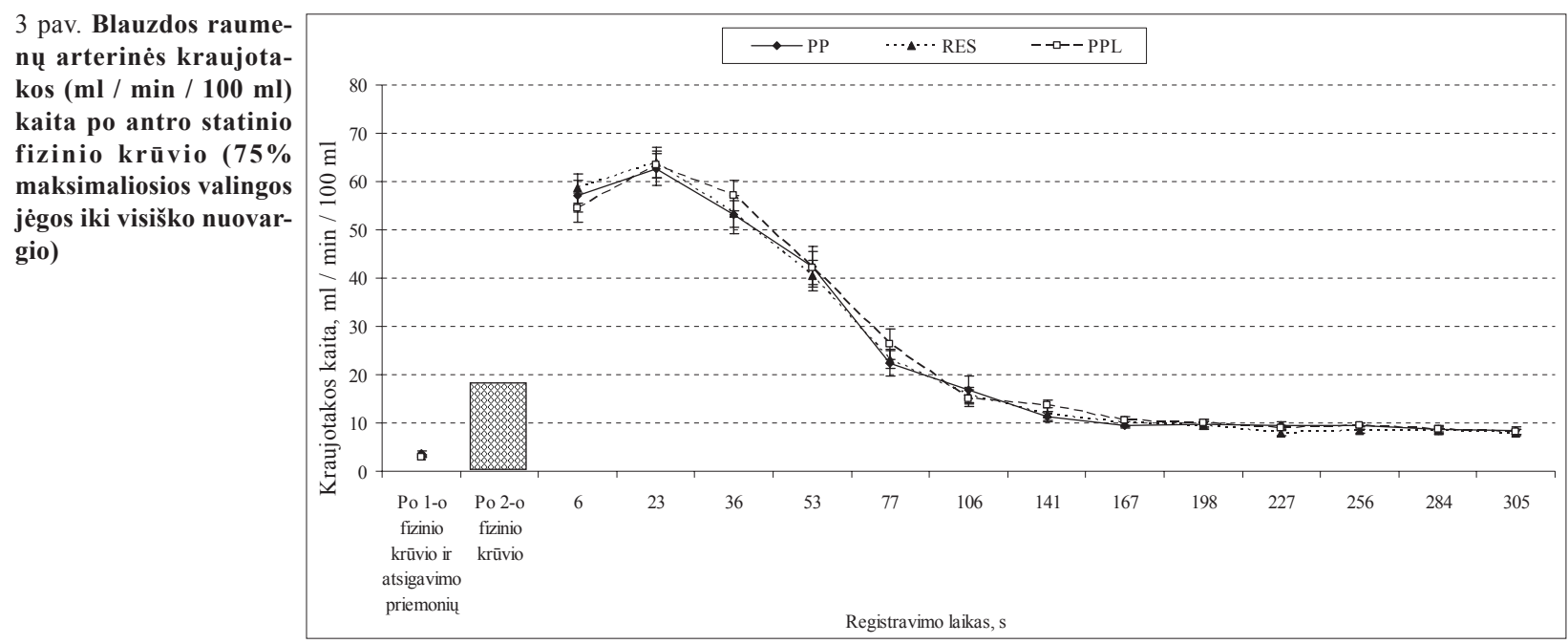

jant griaučiu raumenis elektra, arterinès kraujotakos intensyvumas $(3,3 \pm 0,3 \mathrm{ml} / \mathrm{min} / 100 \mathrm{ml}$, $\mathrm{p}>0,05-5,0 \mathrm{~s} ; 3,1 \pm 0,2 \mathrm{ml} / \mathrm{min} / 100 \mathrm{ml}$, $\mathrm{p}>0,05-28 \mathrm{~s} ; 3,1 \pm 0,2 \mathrm{ml} / \mathrm{min} / 100 \mathrm{ml}$, $\mathrm{p}>0,05-52 \mathrm{~s} ; 3,1 \pm 0,2 \mathrm{ml} / \mathrm{min} / 100 \mathrm{ml}$, $\mathrm{p}>0,05-73 \mathrm{~s})$ buvo šiek tiek didesnis už pradini dydi $(2,6 \pm 0,2 \mathrm{ml} / \mathrm{min} / 100 \mathrm{ml})(2 \mathrm{pav}$.).

Prieš statinį fizinị krūvị pasyvaus pẻdų lenkimo ir tiesimo grupés sportininkų arterinè kraujotaka buvo $2,8 \pm 0,2 \mathrm{ml} / \mathrm{min} / 100 \mathrm{ml}$, tuojau pat po krūvio padidejo $(51,3 \pm 2,7 \mathrm{ml} / \mathrm{min} / 100 \mathrm{ml}, \mathrm{p}<0,001)$, praejjus $305 \mathrm{~s}-7,1 \pm 0,5 \mathrm{ml} / \mathrm{min} / 100 \mathrm{ml}, \mathrm{p}<0,001$ (1 ir 3 pav.). Po fizinio krūvio atliekant pasyvius pédų lenkimo ir tiesimo judesius arterinès kraujotakos intensyvumas $(3,1 \pm 0,3 \mathrm{ml} / \mathrm{min} / 100 \mathrm{ml}$, $\mathrm{p}>0,05-5 \mathrm{~s} ; 2,9 \pm 0,2 \mathrm{ml} / \mathrm{min} / 100 \mathrm{ml}$, $\mathrm{p}>0,05-28 \mathrm{~s} ; 3,0 \pm 0,2 \mathrm{ml} / \mathrm{min} / 100 \mathrm{ml}$, $\mathrm{p}>0,05-52 \mathrm{~s} ; 3,1 \pm 0,2 \mathrm{ml} / \mathrm{min} / 100 \mathrm{ml}$, $\mathrm{p}>0,05-73 \mathrm{~s})$ buvo truputi didesnis už pradini lygi $(2,8 \pm 0,2 \mathrm{ml} / \mathrm{min} / 100 \mathrm{ml})$ (2 pav.). Po fizinio krūvio papildomos atsigavimo priemonès (RES ir PPL) teigiamai veikè arterini kraujotakos intensyvumą ir kraujotaka greičiau sugrižo i pradini lygi.

Po antro statinio fizinio krūvio kraujotakos kaita buvo tokia pat kaip ir po pirmo.

\section{REZULTATU APTARIMAS}

Atsigavimo metu RES teigiamai veikè raumenų funkcinę būklę, nes pẻdos lenkiamųju raumenu darbingumas buvo didesnis nei po pasyviojo poilsio. Galima manyti, kad darbingumo didejimas dirbtinai aktyvinant raumenis elektrostimuliacijos metodu yra susijęs su raumeniniu skaidulu rekrutavimu. Mažieji alfa-motoriniai neuronai inervuoja lètuosius motorinius vienetus, turinčius mažesni jautrumo lygi, o didieji — greituosius (Burke, 1981). Lètieji motoriniai vienetai ima trūkčioti, kai apytikris dažnis $-5-10 \mathrm{~Hz}$, ir tetaninę būsena pasiekia esant $25-30 \mathrm{~Hz}$, o greitiesiems motoriniams vienetams būtinas $80-100 \mathrm{~Hz}$ dažnis (Burke, 1981). Naudotasi elektrostimuliatoriumi, kuriame yra impulsu amplitudinè-dažninė moduliacija, o impulsu dažnis siekè $20-120 \mathrm{~Hz}$. Dirginimo stiprumas - apie $15 \mathrm{~mA}$. Priimama prielaida, kad RES fibriliaciniu režimu (elektromasažo metu) veike mažus ir didelius motorinius vienetus atsigavimo fazejje, todèl stimuliuojamų raumenų funkcinè būsena pagerèjo.

PPL teigiamai veikè raumenų funkcinę būseną atsigavimo laikotarpiu: pėdos lenkiamujų raumenų darbingumas po antro fizinio krūvio reikšmingai padidejo, palyginti su pasyviojo poilsio poveikiu. Raumenų funkcinę būseną veikè arterinès kraujotakos pokyčiai atsigavimo laikotarpiu taikant papildomas atsigavimo priemones (PPL ir RES).

Didžiausios arterinès kraujotakos reikšmès buvo užregistruotos tik po 21 sekundès. Jègos, užspaudžiančios kraujagysles, išnyksta tuoj pat po fizinio krūvio atsipalaidavus raumenims. H. V. Sparks (1964) i̇rode, kad dalis arterijos, veikiama greito ištempimo, susitraukia. R. T. Grant (1930) ištyrè, kad chroniškai denervuotos triušio arteriolès reaguoja ị nestipru prisilietimą vietiškai išsiplèsdamos, i stipru suspaudimą - staigiai, bet vietiškai susitraukda-mos. Vèliau lètai ima reikštis dilatacija. Kodèl kraujotaka didžiausia ne tuoj po fizinio darbo, o po tam tikro laiko, galima paaiškinti remiantis H. V. Sparks ir R. T. Grant tyrimais. Šie autoriai teigia, kad darbo metu arterinès kraujagyslès yra stipriai suspaudžiamos, o po jo reikia laiko, kad arterijos prisipildytų kraujo. 
Joms prisipildžius kraujo, arterinès kraujotakos reikšmès būna didžiausios.

Po fizinio krūvio prasideda darbingumo atsigavimo fazè. Atsigavimo greitis priklauso nuo raumenų kraujotakos intensyvumo. Arterinès kraujotakos intensyvumas po pasyvaus poilsio, prieš antrą statinị fizini krūvị visų matavimų metu $(5 \mathrm{~s}$, $28 \mathrm{~s}, 52 \mathrm{~s}$ ir $73 \mathrm{~s}$ ) buvo didesnis, palyginti su pradiniu dydžiu. Šio rodiklio intensyvumui turi itakos padidejęs metabolitų kiekis ir deguonies trūkumas. Suaktyvinus kraujotaką RES metodu, atsigavimo laikotarpiu greičiau pašalinami iš organizmo metabolitai ir geriau pernešamas deguonis i dirbusius raumenis. Galima teigti, kad dèl RES poveikio arterinès kraujotakos intensyvumas greičiau sumažeja iki pradinio dydžio. Raumuo nevarginamas, jei jaudinimo stiprumas sukelia tik matomus pavieniu raumeninių skaidulu susitraukimus, o visas raumuo nesusitraukia. Toks elektromasažas padidina raumenų kraujotakos intensyvumą apie $20-30 \%$, palyginti su ramybès būsena (Кибиша и др., 1983).

Taikant PPL prieš antrą fizinị krūvị arterinè kraujotaka buvo šiek tiek didesnè $(p>0,5)$ už pradini dydi. PPL metu vyksta išilginis raumenu tempimas ir trumpejiimas. Eksperimentai su gyvūnais parodè (Fales et al., 1962; Brandi et al., 1969; Matsen et al., 1977), kad tokiu būdu tempiant gyvūnų išilginius raumenis kraujotaka mažeja dèl tempimo metu padidejusio slègio tarp raumenu, t. y. dèl atsiradusios kraujagysles veikiančių ir suspaudžiančių aplinkinių audinių jègos. Slègis kraujagyslèse padideja. Hidraulinis pasipriešinimas taip pat dideja (spindis sumažeja) ilgejjant kraujagyslëms (Kirkebo, Wisnes, 1982).

Deguonies vartojimo intensyvumas raumenyse priklauso nuo jų kraujotakos intensyvumo ne tik fizinio krūvio pradžioje, bet ir jo metu (Gonzalez-Alonso, Calbert, 2003) atsigavimo po krūvio laikotarpiu (Crisafulli et al., 2006). Raumenuc kraujotakos kaita tiesiogiai veikia oksidaciniu metabolinių procesų intensyvumą (Friedmann et al., 2007), todèl tikètina, kad aktyvinant raumenu kraujotaką galima padidinti kvèpavimo greiti audiniuose, pagerinti raumenu darbingumą.

\section{IŠVADOS}

1. Sportininkams taikomos papildomos atsigavimo priemonès - pasyvus pèdų lenkimas ir tiesimas, raumenu elektrostimuliacija po statinio fizinio krūvio - skatina pėdos lenkiamujų raumenų darbingumo atsigavimą.

2. Raumenų elektrostimuliacija, pasyvus pèdų lenkimas ir tiesimas atsigavimo laikotarpiu didina arterinès kraujotakos intensyvumą ir ji greičiau grižta i pradini lygi.

\section{LITERATŪRA}

Bonnaire, F., Brandt, T., Raedecke, J., Bonk, A. (1994). Mechanical dynamic ankle passive motion for physical prevention of thrombosis? Changes in hemodynamics in the lower pressure system with new dynamic splints. Der Unfallchirurg, 97, 366-371.

Boutcher, Y. N., Boutcher, S. H. (2005). Limb vasodilatory capacity and venous capacitance of trained runners and untrained males. European Journal of Applied Physiology, 95 (1), 83-87.

Brandi, G., McGregor, M. (1969). Intramural pressure in the left ventricle of the dog. Cardiovascular Research, 3 (4), 472-475.

Brocherie, F., Babault, N., Cometti, G., Maffiuleti, N., Chatard, J. C. (2005). Electrostimulation training effects on the physical performance of ice hockey players. Medicine and Science in Sports and Exercise, 37, 455- 460.

Burke, R. E. (1981). Motors units: Anatomy, physiology and functional organization. In V. B. Brooks (Ed.), Handbook of Physiology Section 1: The Nervous System. Vol. III. Motor Systems, American Physiology Society, Bethesda, MD. P. 345-422.

Crisafulli, A., Orru, V., Melis, F., Tocco, F., Concu, A. (2003). Hemodynamics during active and passive recovery from a single bout of supramaximal. European Journal of Applied Physiology, 89 (2), 209-216.
Crisafulli, A., Tocco, F., Pittau, G. et al. (2006). Effect of differences in post-exercise lactate accumulation in athletes' haemodynamics. Applied Physiology, Nutrition, and Metabolism, 31 (4), 423-431.

Fales, I. T, Heisey, R. S., Zierler, K. L. (1962). Blood flow from and oxygen uptake by muscle during and after partial venous occlusion. American Journal of Physiology, 203, $470-474$.

Friedmann, B., Frese F., Menold, E., Bartsh, P. (2007). Effects of acute moderate hypoxia on anaerobic capacity in endurance-trained runners. European Journal of Applied Physiology, 101 (1), 67-73.

Grant, R. T. (1930). Observations on local arterial reactions in rabbit's ear. Heart, 15, 257-271.

Gonzalez-Alonso, J., Calbet, J. A. (2003). Reductions in systemic and skeletal muscle blood flow and oxygen delivery limit maximal aerobic capacity in humans. Circulation, 107 (6), 824-830.

Gonzalez-Alonso, J., Mortensen, S. P., Jeppesen, T. D. et al. (2008). Haemodynamic responses to exercise, ATP infusion and thigh compression in humans: Insight into the role of muscle mechanisms on cardiovascular function. The Journal of Physiology, 586 (9), 2405-2417.

Hughson, R. L., Shoemaker, J. K., Tschakovsky, M. E., Kowalchuk, J. M. (1996). Dependence of muscle $\mathrm{VO}_{2}$ on 
blood flow dynamics at onset of forearm exercise. Journal of Applied Physiology, 81 (4), 1619-1626.

Kirkebo, A., Wisnes, A. (1982). Regional tissue fluid pressure in rat calf muscle during sustained contraction or stretch. Acta Physiologica Scandinavica, 114 (4), $551-556$.

Lavec, G., Millet, G. P., Jougla, A., Micallef, J. P., Bendahan, D. (2008). Electrostimulation improves muscle perfusion but does not affect either muscle deoxygenation or pulmonary oxygen consumption kinetics during a heavy constant-load exercise. European Journal of Applied Physiology, 102 (3), 289-297.

Macarez, J. A. (1976). La place du réflexogramme achilléen dans l'examen médico-sportif. Symbioses, 8 (4), 261-274.

Maffiulleti, N. A., Cometti, G., Amiridis, I. G. et al. (2000). The effects of electrostimulation training and basketball practice on muscle strength and jumping ability. International Journal of Sports Medicine, 21, 437-443.

Maffiulleti, N. A., Dugnani, S., Folz, M., Di Pierno, E., Mauro, F. (2002). Effect of combined electrostimulation and plyometric training on vertical jump height. Medicine and Science in Sports and Exercise, 34, 1638-1644.

Maffiulleti, N. A., Zory, M., Miotti, D. et al. (2006). Neuromuscular adaptations to electrostimulation resistance training. American Journal of Physical Medicine and Rehabilitation, 85, 167-175.

Malatesta, D., Cattaneo, F., Dugnani, S., Maffiuleti, N. A. (2003). Effects of electrostimulation training and volleyball practice on jumping ability. The Journal of Strength and Conditioning Research, 17, 573-579.

Matsen, F. A., Mayo, K. A., Sheridan, Y. W., Krugmire, R. B. (1977). Continuous monitoring of intramuscular pressure and its application to clinical compartmental syndromes. Bibliotheca Anatomica, (15 Pt 1), 112-115.

Mcnair, P. J., Dombroski, E. W., Hewson, D. J., Stanley, S. N. (2001). Stretching at the ankle joint: Viscoelastic responses to holds and continuous passive motion. Medicine and Science in Sports and Exercise, 33, 354-358.

Sochart, D. H., Hardinge K. (1999). The relationship of foot and ankle movements to venous return in the lower limb. The Journal of Bone and Joint Surgery, 81, $700-704$.

Sparks, H. V. (1964). Effect of quick stretch of isolated vascular smooth muscle. Circulation Research, 15, 254-260.

Sweeney, J. D. (1998). Skeletal muscle response to electrical stimulation. In J. P. Reilly (Ed.), Applied Bioelectricity: From Electrical Stimulation to Electropathology (pp. 299-340). New York: Springer-Verlag.

Therault, R., Boulay, M. R., Therault, G., Simoneau, J. A. (1996). Electrical stimulation-induced changes in performance and fiber type proportion of human knee extensor muscles. European Journal of Applied Physiology and Occupational Physiology, 74, 311-317.

Кибиша, Р. П., Бредикис, Ю. Ю., Пукас, А. (1980). Устройство для массажа конечностей. Изобр. №766597 от 6.07.1980.

Кибиша, Р. П., Подерис, И. А., Грюновас, А. П. (1983). Применение электростимуляции мыши и пассивных движений стоп для восстановления работоспособности: методические рекомендации. Каунас.

Платонов, В. Н. (2004). Система подготовки спортсменов в олимпийском спорте: общая теория и её практическое приложение. Киев: Олимпийская литература.

\title{
THE EFFECT OF MEANS OF RECOVERY ON FUNCTIONAL CONDITION OF CALF MUSCLES AND BLOOD CIRCULATION AFTER STATIC PHYSICAL EXERCISE
}

\author{
Albinas Grūnovas ${ }^{1}$, Jonas Poderys ${ }^{1}$, Danguolè Grūnovien $\dot{e}^{2}$ \\ Lithuanian Academy of Physical Education ${ }^{1}$, Kaunas College ${ }^{2}$, Kaunas, Lithuania
}

\begin{abstract}
Working capacity and recovery of the athlete's body function after exhaustive exercising depends on a number of factors among which a special place is taken by peculiarities of systemic and muscular blood circulation. The final result, i. e. intensity of blood circulation is determined by various regulatory mechanism and their interaction. In search of more efficient solution of activating of blood circulation by supplementary means of recovery are suggested.

This research was aimed at analysing the effect of electrical stimulation of the skeletal muscle (ESSM), passive foot flexion (PFF) and passive rest (PR) on functional condition of muscles and blood circulation after static physical exercise.

The research involved 22 endurance athletes. After establishing the arterial blood circulation in conditions of rest, having used the method of venous occlusive plethysmography by means of the method of dynamometry the force of foot flexors was measured and the first local static physical exercise (resistance
\end{abstract}


up to $75 \%$ of maximum voluntary force) till exhaustion was undertaken. After the first and the second static physical load changes in calf muscles were registered for $305 \mathrm{~s}$. Through the research an interval of $20 \mathrm{~min}$ was retained between the two physical exercises. After the first static physical load having registered blood circulation three types of recovery means, i. e. ESSM, PFF and PR were applied..

In the PR group prior to static physical load the arterial blood circulation was $2.7 \pm 0.2 \mathrm{ml} / \mathrm{min} / 100 \mathrm{ml}$ and then it increased $52.4 \pm 3.3 \mathrm{ml} / \mathrm{min} / 100 \mathrm{ml}(\mathrm{p}<0.001)$. After $305 \mathrm{~s}$ the arterial blood circulation and after PR was $4.0 \pm 0.3 \mathrm{ml} / \mathrm{min} / 100 \mathrm{ml}(\mathrm{p}<0.05)$. In the ESSM group prior to static physical load the arterial blood circulation was $2.6 \pm 0.2 \mathrm{ml} / \mathrm{min} / 100 \mathrm{ml}$ and then it increased $55.8 \pm 3.4 \mathrm{ml} / \mathrm{min} / 100 \mathrm{ml}(\mathrm{p}<0.001)$. After $305 \mathrm{~s}$ the arterial blood circulation and after applying ESSM was $3.3 \pm 0.3 \mathrm{ml} / \mathrm{min} / 100 \mathrm{ml}(\mathrm{p}>0.05)$. In the PFF group prior to static physical load the arterial blood circulation was $2.8 \pm 0.2 \mathrm{ml} / \mathrm{min} / 100 \mathrm{ml}$ and then it increased $51.3 \pm 2.7 \mathrm{ml} / \mathrm{min} / 100 \mathrm{ml}(\mathrm{p}<0.001)$. After $305 \mathrm{~s}$ the arterial blood circulation and after applying PFF it was $3.1 \pm 0.3 \mathrm{ml} / \mathrm{min} / 100 \mathrm{ml}(\mathrm{p}>0.05)$. Applying the additional means for recovery after physical load has made an influence on the intensity of arterial blood flow in muscles why the faster recovery up to initial level was observed.

After applying ESSM the working capacity of foot flexors increased by $0.2 \%$, after PFF applied - by $8.2 \%$ and after applying PR the working capacity of foot flexors had decreased by $8,2 \%$ accordingly. After the second static load changes in the arterial blood circulation were analogous to those registered after the first static load.

Conclusions. Passive foot flexion and electrical stimulation as the additional means for recovery applied after isometric workload stimulated the recovery of muscular performance. The efficiency of passive foot movements was higher than electrical stimulation. Applying the means of electrical stimulation of the muscles, passive foot flexion stimulates the processes of recovery and the arterial blood circulation faster returns to its basic level.

Keywords: physical capacity, muscle blood flow, recovery means. 